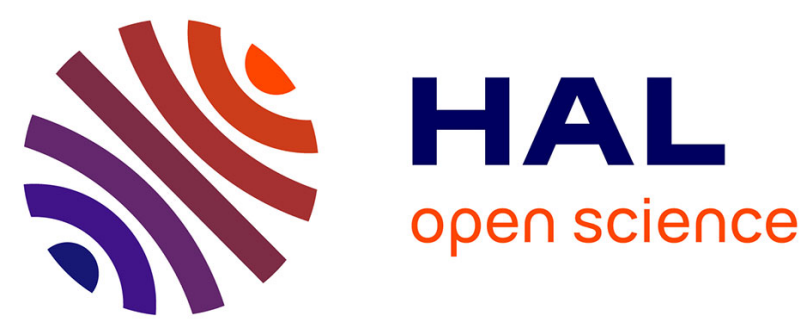

\title{
From stream to land: Ecosystem services provided by stream insects to agriculture
}

Julien Raitif, Manuel Plantegenest, Jean-Marc Roussel

\section{To cite this version:}

Julien Raitif, Manuel Plantegenest, Jean-Marc Roussel. From stream to land: Ecosystem services provided by stream insects to agriculture. Agriculture, Ecosystems and Environment, 2019, 270-271, pp.32-40. 10.1016/j.agee.2018.10.013 . hal-02272263

\section{HAL Id: hal-02272263}

\section{https://institut-agro-rennes-angers.hal.science/hal-02272263}

Submitted on 27 Aug 2019

HAL is a multi-disciplinary open access archive for the deposit and dissemination of scientific research documents, whether they are published or not. The documents may come from teaching and research institutions in France or abroad, or from public or private research centers.
L'archive ouverte pluridisciplinaire HAL, est destinée au dépôt et à la diffusion de documents scientifiques de niveau recherche, publiés ou non, émanant des établissements d'enseignement et de recherche français ou étrangers, des laboratoires publics ou privés.

\section{(1)(1) $\$(0)$}

Distributed under a Creative Commons Attribution - NonCommercial - ShareAlikel 4.0 
Agriculture, Ecosystems and Environment

Elsevier Editorial System(tm) for

Manuscript Draft

Manuscript Number: AGEE19620R2

Title: From stream to land: ecosystem services provided by stream insects to agriculture

Article Type: Review Article

Keywords: aquatic subsidies; agroecosystems; winged aquatic insects; pollination; soil fertilization; biological control

Corresponding Author: Mr. Julien RAITIF,

Corresponding Author's Institution: INRA

First Author: Julien RAITIF

Order of Authors: Julien RAITIF; Manuel Plantegenest; Jean-Marc Roussel

Manuscript Region of Origin: FRANCE

Abstract: The connection between aquatic ( (3) terrestrial habitats has increased scientific interest in ecological subsidies, focusing on how the transfer of matter and energy betifen adjacent ecosystems can modify the ecosystems functioning. Much attention has focused on subsidies associated with winged aquatic inse 0 . I pristine areas, but their existence and implications in agrisutural landscapes are rarely considered. We reviewed current know7edge on the dominant types of winged stream insects involved in terrej-ral ecosystem subsidizing and how agricultural practices can aff(et) their communities. We compiled published data that illustretre contribution of winged stream insects to ecological services in achecosystems. Agricultural intensification has resulted in profound environmental modifications of streams and a decrease in large-bodied and sensitive taxa of Ephemera, Plecoptera and, to a lesser degree, Trichoptera orders, whereas more tolerant and smallbodied taxa of the Diptera order may increase. In return, these changes in stream invertebrate communities can modify the transfer of aquatic subsidies to agroecosystems. Winged stream insects can disperse up to 150 $\mathrm{m}$ from the stream bank, depending on species. They pollinate both wild and cultivated plants, fertilize the soil (depositing up to $12 \mathrm{mg} \mathrm{N} / \mathrm{m} 2$ per day) during emergence outbreaks and feed natural enemies of crop pests during crucial periods of the year. Promising evidence suggests that they can support the related ecosystem services (pollination, soil fertilization and crop pest control), indicating the need for further research. Another area of focus can include the influence of agricultural practices on the amount and type of emerging aquatic insects. Future research on aquatic subsidies in agricultural landscapes may provide new insights into the management and provision of ecosystem services to agriculture, while simultaneously ensuring the conservation of rich freshwater biodiversity for optimal ecosystem functioning. 


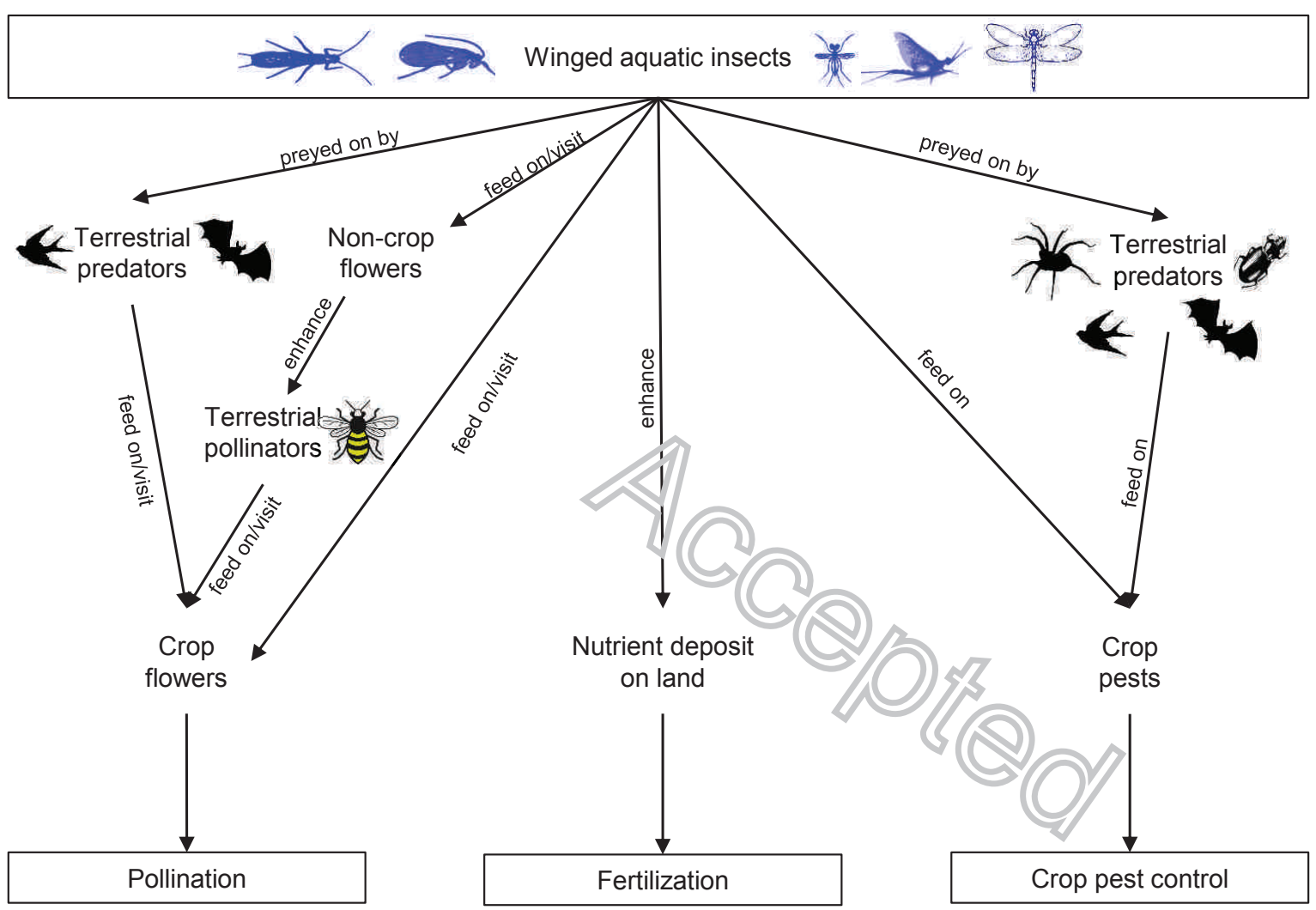


Graphical abstract: Potential ecosystem services supported by winged stream insects

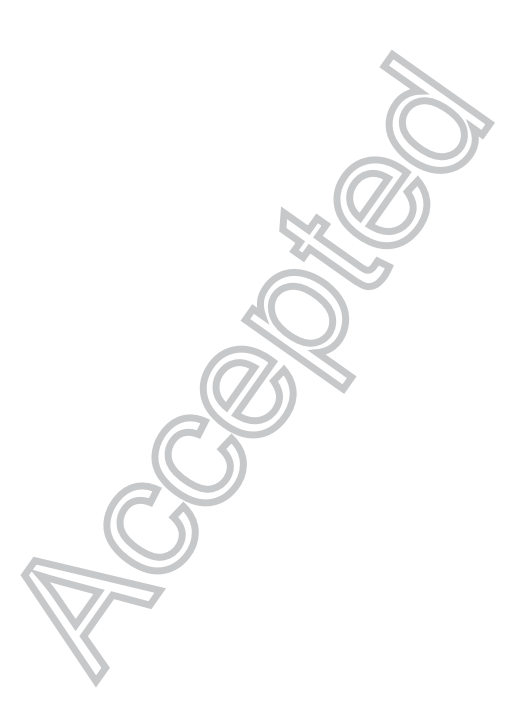

Graphical Abstract legend 
Highlights

- We review how agriculture affects winged insects emerging from streams

- Shifts in communities are observed, promoting small-bodied and more mobile taxa

- Changes in the transfer of aquatic subsidies to agroecosystems are reported

- Pollination, fertilization and biological control services could be altered

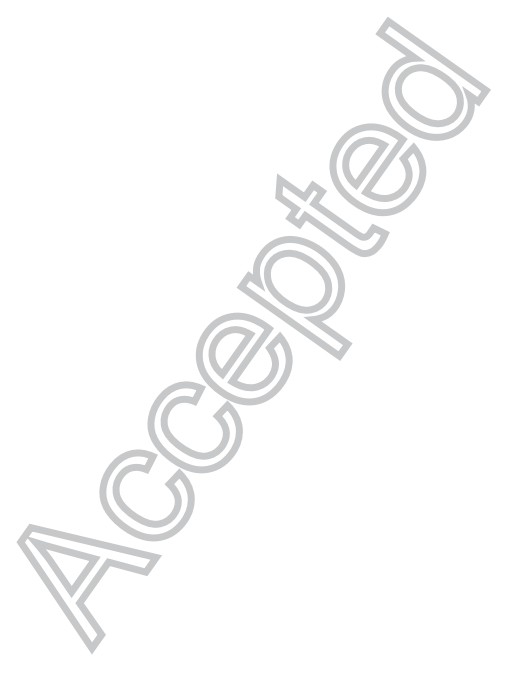


From stream to land: ecosystem services provided by stream insects to agriculture

Raitif Julien $^{1,2}$, Manuel Plantegenest ${ }^{2}$, Jean-Marc Roussel ${ }^{1,3}$

${ }^{1}$ INRA, Agrocampus-Ouest, Ecology and Ecosystem Health, 65 rue de Saint-Brieuc, Rennes, France

${ }^{2}$ IGEPP, Institut de Génétique, Environnement et Protoctines des Plantes, Agrocampus Ouest, 65 rue de Saint Brieuc, Rennes, France

${ }^{3}$ Management of aquatic ecosystems in agri-arfuai vatersheds, INRA, Agence Française pour la Biodiversité, Rennes, France 
2 The connection between aquatic and terrestrial habitats has increased scientific interest in

3 ecological subsidies, focusing on how the transfer of matter and energy between adjacent

4 ecosystems can modify the ecosystems functioning. Much attention has focused on subsidies

5 associated with winged aquatic insects in pristine areas, but their existence and implications in

6 agricultural landscapes are rarely considered. We reviewed current knowledge on the

7 dominant types of winged stream insects involved in terrestrial ecosystem subsidizing and

8 how agricultural practices can affect their communities. We compiled published data that

9 illustrate the contribution of winged stream insects to ecological services in agroecosystems.

10 Agricultural intensification has resulted in profound en ironmental modifications of streams

11 and a decrease in large-bodied and sensitive taxa of Fmh tme ra, Plecoptera and, to a lesser

12 degree, Trichoptera orders, whereas more tolerant and small-bodied taxa of the Diptera order

13 may increase. In return, these changes in strem in rtebrate communities can modify the

14 transfer of aquatic subsidies to agroecosy ems. Winged stream insects can disperse up to 150

$15 \mathrm{~m}$ from the stream bank, depending on ner. es. They pollinate both wild and cultivated plants,

16 fertilize the soil (depositing up to $12 \mathrm{ng} \mathrm{N} / \mathrm{m}^{2}$ per day) during emergence outbreaks and feed

17 natural enemies of crop pests during crucial periods of the year. Promising evidence suggests

18 that they can support the related ecosystem services (pollination, soil fertilization and crop

19 pest control), indicating the need for further research. Another area of focus can include the

20 influence of agricultural practices on the amount and type of emerging aquatic insects. Future

21 research on aquatic subsidies in agricultural landscapes may provide new insights into the

22 management and provision of ecosystem services to agriculture, while simultaneously

23 ensuring the conservation of rich freshwater biodiversity for optimal ecosystem functioning.

24 Keywords: aquatic subsidies; agroecosystems; winged aquatic insects; pollination; soil

25 fertilization; biological control 
In recent decades, ecologists have explored the interactions between entities (e.g. individuals or groups of individuals) previously considered isolated from each other. A growing body of literature has substantially expanded the theoretical background from populations to communities, focusing notably on the influence of landscape heterogeneity on community structure (Holt 1997). More recently, the concept of meta-ecosystems has emerged (Loreau et al. 2003), which is based on the assertion that adjacent ecosystems in heterogeneous landscapes exchange matter and energy. Although ecology has identified the existence of such transfers, they were ignored until recently. In the $19^{\text {th }}$ century, the entomologist John Gould (1804-1881) observed birds preying on dragonflies (in Sallinger and Lake 2006), and in the early $20^{\text {th }}$ century it was acknowledged that energy could woss ecosystem boundaries (Summerhayes and Elton 1923). In the late 1970s. C.dum et al. (1979) highlighted that allochthonous inputs from an ecosystem could modity the functioning of the adjacent recipient ecosystem, initiating a promisin t1e d of rearch in ecology. A pioneer study by Polis et al. (1997) provided a theoretica bas, is, stating that the significance of allochthonous inputs, also referred to as "subsidies", was expected to vary according to autochthonous food abundance in the receiving ecosystem, i.e. its productivity. Predicting the effects of subsidies remains complex and depends on the type of subsidy, the trophic levels involved and the amount of resources provided to the receiving food web (Marczak et al. 2007). Multiple case studies from a wide diversity of ecosystems provide clear evidence that food webs are fueled by subsidies (e.g. Jackson and Fisher 1986; Gray 1989; Polis and Hurd 1995; Dreyer et al. 2012; Havik et al. 2014).

Interconnections between land and water are common in many ecosystems (Larsen et al. 2015), and the connection between aquatic and terrestrial habitats has prompted scientific interest. Until recently, most literature described how physical laws determined the transfer of 
subsidies to aquatic ecosystems. For instance, riparian tree leaves falling in the water sustain the detrital pathway in heterotrophic headwater streams (Vannote et al. 1980). At the watershed scale, fertilizer leakage across agricultural landscapes affects primary production and aquatic food webs, and ultimately has subtle effects on nutrient cycling in streams (Roussel et al. 2014). Conversely, deposition of nutrient-rich sediments from streams to valleys during flooding supported the emergence of agriculture in the Fertile Crescent during the Neolithic (Mazoyer and Roudart 2006). In estuaries and marine coastal areas, benthic food webs are largely fueled by terrestrial organic subsidies conveyed by rivers (Kostecki et al. 2010), while tidal surges and wind can transfer huge amounts of marine inputs to terrestrial habitats (Hyndes et al. 2014).

Based on the assumed prominent role of physical laws in wosidy transfers, aquatic ecosystems have long been considered as passive iceryers of terrestrial subsidies. This paradigm was challenged when Polis et al. (10n - nphasized the role of living organisms in the reciprocal transfer from aquatic to terrestral ecosystems. Examples exist of terrestrial and avian predators foraging in aquatic ecosst $\mathrm{ms}$, which ultimately fertilize terrestrial ecosystems (e.g. Havik et al. 2014). - dditionally, arthropods metamorphosing from aquatic larvae to aerial adults are suitable candidates for reciprocal transfers of matter and energy from water to land (Schulz et al. 2015). They are common in all aquatic ecosystems, disperse towards land as winged adults, and are involved in nutrient cycling and the functioning of food webs (Baxter et al. 2005). Some studies have identified the important role of adult aquatic arthropods in the diet of terrestrial carabids (Hering and Plachter 1997), spiders (Paetzold et al. 2005), birds (Nakano and Murakami 2001) and lizards (Sabo and Power 2002). Recently, the meta-analysis by Bartels et al. (2012) highlighted that even though the mass of aquatic subsidies to land is lower than the reciprocal mass of terrestrial subsidies, their average contributions to the functioning of receiving food webs appeared to be similar. 
Differences in the quality of subsidies could explain this unexpected result; aquatic insects are nutrient-rich, especially in nitrogen $(\mathrm{N})$ and lipids, whereas freshwater receives mainly carbon-rich detrital organic matter (OM) from terrestrial plants.

Despite increasing evidence about the ecological importance of aquatic subsidies in terrestrial ecosystems, studies have focused mainly on forests and grasslands. Even though freshwater ecosystems are widespread in agricultural landscapes, the possible roles of aquatic subsidies are rarely considered. Depending on the aquatic species and its behavior as a winged adult in agroecosystems, they may support services to agriculture. This article aims to present the dominant types of winged aquatic insects involved in terrestrial ecosystem subsidizing and how agriculture can influence the magnitude of these stisidies through its impacts on aquatic communities. Our analysis focuses on streams due to the revalence and extended interfaces with croplands and pastures. We chose to highlight the contribution of stream arthropods to three major ecosystem services to agriculture polination, fertilization and biocontrol - and to assess it from data available in the literature

\section{Effects of agriculture on stren insert communities}

The composition of stream insect communities varies among streams and from headwater tributaries to downstream sections, as a function of the habitats and food sources available (Vannote et al. 1980). In agricultural streams, most taxa with a winged adult stage are reported to belong to the following orders: Ephemeroptera, Plecoptera, Trichoptera (referred to as EPT) and Diptera. Inland dispersal of adult aquatic insects depends on their morphology and feeding and reproductive behaviors and thus differs greatly among orders (Muehlbauer et al. 2014). In the following sections, we emphasize how agricultural practices alter stream invertebrate composition and, in return, can modify the amount and quality of winged aquatic insects transferred to agroecosystems. 
101 The multiple energy pathways that flow in aquatic food webs, i.e. autotrophy and

102 heterotrophy, depend on the availability of basal sources for primary consumers and higher-

103 level predators through bottom-up effects. Heterotrophy dominates in narrow, light-limited

104 headwater streams, where a significant portion of OM comes from riparian tree leaves, even

105 though algae provide consumers with essential amino acids and fatty acids (Brett et al. 2017).

106 The contribution of autotrophy likely increases downstream in larger, open water streams,

107 where aquatic primary productivity increases (algae, macrophytes) before being hampered

108 further downstream in more turbid water, where heterotrophy is enhanced by fine particles

109 from terrestrial runoff (Vannote et al. 1980). Stream invertebrates, especially primary

110 consumers, can be classified into functional groups acsoring to the nature of OM they feed

111 on. Along the upstream-downstream continuum, in wertebrate communities tend to gradually

112 shift from shredders and grazers in headwater to filer-feeders and collector/gatherers in

113 larger streams (Lancaster 2013).

114 Human activities that modify wat hed regetation and land cover influence the quantity and 115 quality of basal carbon sources in stre.ms. Lu et al. (2014) reported that land use significantly

116 altered the nutritional value of OM (estimated from lipid concentration). Bellamy et al. (2017)

117 highlighted how these changes in basal feeding sources due to agricultural pressure influenced 118 aquatic macroinvertebrates differently according to their functional feeding group (FFG).

119 Notably collector/gatherers (Ephemerella mayflies) were more reliant on terrestrial and soil $120 \mathrm{OM}$ in agricultural landscape, a shift imputed to increased sedimentation. Deegan and Ganf

121 (2008) showed how loss of riparian vegetation could significantly constrain shredder

122 communities in Australian streams via the collapse of an adequate food source.

123 Anthropogenic inputs of nutrients from agricultural fertilizers have increased greatly over the 124 past century in nearly all parts of the world (Galloway et al. 2008). Nutrient concentrations 
have increased in streams, stimulating the autotrophic energy pathway. A large amount of

126 literature illustrates how benthic invertebrate communities are subsequently altered via

127 bottom-up transfers within aquatic food webs; however, multiple outcomes are reported.

128 Davis et al. (2011) showed a two-fold increase in stream secondary production after 5 years

129 of experimental addition of nutrients. They observed that larger Trichoptera emerged from the

130 stream but were not more abundant. Cross et al. (2006) reported that benthic invertebrate

131 biomass significantly increased after 2 years of enrichment of a headwater stream, but with a

132 magnitude depending on the FFG. More recently, Raitif et al. (2018) studied 12 streams

133 located in an intensive agricultural landscape. They reported that the proportion of agricultural

134 land and ammonium concentration in water influenced significantly and positively the

135 emerging drymass of Chironomidae while decreasing thet of Ephemeroptera.

136 Intensification of agricultural practices has resulte 1 in a large increase in pesticide use, which

137 has been clearly identified as a major stressor for riany aquatic species. They show

138 contrasting susceptibility to pesticides, re itec in particular to life-cycle traits such as

139 generation time and the presence of sensitive aquatic stages during pesticide exposure, as

140 proposed by Liess and Von Der Ohe (2005). Analyzing the effect of agricultural pesticides on

141 the taxa richness of stream invertebrates in 72 sites in Europe and Australia, Beketov et al.

142 (2013) found a decrease up to $42 \%$ in family richness between uncontaminated and highly

143 contaminated streams. Following the species-at-risk (SPEAR) method, which estimates the

144 sensitivity of aquatic invertebrates to pesticide exposure, Plecoptera and Ephemeroptera are

145 considered more sensitive taxa than Diptera and Trichoptera (Wogram and Liess 2001).

\subsection{Water temperature, flow and substrate}

147 Water temperature is a major driver of insect biology in freshwater ecosystems because it

148 directly affects insect metabolism (Vannote and Sweeney 1980). Eurythermal species can

149 develop under a wide range of temperatures, unlike stenothermal species (Ward and Stanford 
1982). Several processes, in connection with air temperature and climate at a large continental

151 scale, explain the variation in water temperature, as do local influences, including

152 groundwater exchanges and shade (reviewed by Webb et al. 2008). Nagasaka and Nakamura

153 (1999) estimated that agricultural intensification in Japan since 1945, especially clearing of

154 riparian vegetation and river channelization (the widening and deepening of a river channel),

155 had increased the maximum temperature of some rivers from $22^{\circ} \mathrm{C}$ to $28^{\circ} \mathrm{C}$.

156 Shifts in aquatic invertebrate community composition are frequently associated with an

157 increase in stream temperatures, especially for stenothermal EPT families (Sponseller et al.

158 2001; Haidekker and Hering 2008). Sponseller et al. (2001) observed that aquatic

159 macroinvertebrate diversity was negatively correlated th stream temperature, since

160 eurythermal taxa such as chironomids dominate in wame-reams. A similar pattern was also

161 reported by Kiffney et al. (2003) who found more orronomids in sites with narrow riparian

162 vegetation, more light and higher water temperat ures. However, when temperature stays

163 inside the tolerance limits, warmer tempe iture can enhance the emerging drymass of

164 Trichoptera and Ephemeroptera (Raitifet cl. 2018).

165 The effect of increasing temperature ater the clearing of riparian vegetation may be further

166 exacerbated by global warming, which increases the threat to cold-stenothermal taxa. In their

167 review of 297 sites in the western United States (U.S.), Poff et al. (2010) showed that the

168 expected increase in temperature by the end of the 21 st century could replace many cold-

169 stenothermal taxa, especially those in the Plecoptera order, with eurythermal species of

170 Diptera and Trichoptera, potentially resulting in profound consequences for stream ecology.

171 Habitat conditions in streams also influence invertebrate communities, especially hydraulic

172 conditions and the type of substrate. For instance, floods and droughts exert pressures that

173 select morphological, physiological or behavioral traits of aquatic insects in response to these

174 perturbations (Bunn and Arthington 2002). Regulating river discharges, in connection with 
175 hydroelectricity production, water supply or irrigation, can decrease aquatic insect diversity, especially by reducing habitat diversity, food availability and affecting thermal regime. Low taxa richness is often observed in regulated rivers, promoting chironomids and other flexible taxa such as certain Ephemerellidae at the expense of other sensitive mayflies (Heptageniidae) (Brittain and Saltveit 1989; Munn and Brusven 1991). At local scales, the succession of pool 180 and riffle habitats hosts multiple assemblages of macroinvertebrates (Brown and Brussock 181 1991). Ephemeroptera and Trichoptera are generally more abundant in riffle habitats, whose larger substratum particles provide foraging sites for grazers and filter feeders in these orders.

183 Conversely, burrowers and collector/gatherers of the Diptera order (e.g. chironomids) prevail 184 in pools, where water velocity is low and the substratum is fine sediment (Logan and Brooker 185 1983). Channelization alters water flow and aquatic habitat cterogeneity. In a study along the 186 Rio Grande River in New Mexico, U.S., Kennedy and I. rner (2011) found that channelization reduced the density and diversit of quatic macroinvertebrates and resulted in outbreaks of chironomids and a loss of maventite in most agricultural areas, river channels

189 have been reshaped to facilitate crop irigation and reduce flooding risks. The resulting loss in 190 aquatic habitat heterogeneity induc 2 decrease in macroinvertebrate species abundance and 191 diversity. Negishi et al. (2002) highlighted that the decrease in bottom invertebrate shelters in 192 a channelized section of a stream endangers community recovery after flood episode, 193 resulting in a lower density of macroinvertebrates than in natural sections. Altering stream 194 morphology has a strong influence on the hyporheic zone, where most aquatic invertebrates 195 seek refuge during hydrological disturbances (Dole-Olivier 2011).

196 The silting of streams, often observed in agricultural landscapes following clearing of 197 terrestrial vegetation, can also influence aquatic macroinvertebrate assemblages greatly (Allan 198 2004). Excess sediment loads in stream beds, resulting from greater terrestrial surface runoff, 199 clog vital habitats for many aquatic insects, which significantly reduces the relative 
abundance of sensitive EPT taxa (Burdon et al. 2013). By altering food availability, they also

201 constrain aquatic insects to different degrees as a function of their FFG. Several studies show

202 that siltation decreases filter-feeding and grazer taxa density and diversity, especially EPT

203 taxa (Lemly 1982, Wagenhoff et al. 2011). Conversely, collectors/gatherers that burrow in silt

204 can benefit from fine sediments, especially chironomids (Lemly 1982, Rabení et al. 2005).

\section{Effects of agriculture on stream insect subsidies}

206 As illustrated in section 2, much evidence suggests that agricultural practices significantly 207 influence stream invertebrate communities and that Diptera species, especially chironomids, 208 often become dominant in agricultural landscapes at the expense of EPT species (Figure 1).

209 Few reliable studies exist that extend this finding to wind adults, and the consequences of 210 agricultural practices on the magnitude of stream ins cts sosidies are not yet clearly

211 established. However, recent studies demonstrat o hat agriculture influences the magnitude

212 of aquatic exports and their assimilation in the restial food web.

\subsection{Modification of the flux of aquatisusidies}

214 Greenwood and Booker (2016) high $y$ ghted that agricultural intensification in watersheds in

215 New Zealand resulted in a significant increase in the density of stream larvae species that

216 become terrestrial winged adults. The authors also showed a shift towards smaller

217 invertebrates with greater adult dispersal abilities, suggesting potentially greater export of

218 aquatic insects toward land. Similarly, Stenroth et al. (2015) showed that land use can

219 influence the size of the assemblage of emerging insects, with small aquatic insects being

220 more abundant in agricultural areas. However, they did not observe s changes in the biomass

221 of aquatic subsidies. In Sweden, Carlson et al. (2016) found more winged aquatic insects near 222 agricultural streams than near forested streams, especially small Diptera taxa (Chironomidae). 223 In France, Delettre and Morvan (2000) studied chironomid dispersal and concluded that it was 
224 restricted to stream corridors with dense riparian vegetation, whereas long-distance flights

225 over terrestrial landscapes were observed from more open agricultural streams. Raitif et al.

226 (2018) highlighted the role of agriculture in the amount of insect biomass emerging from

227 small streams, and they estimated that aquatic drymass deposit on lands could range between

2280.9 and $4.5 \mathrm{~kg} \mathrm{ha}^{-1}$ year $^{-1}$ in the vicinity of these streams.

\subsection{Cascading effects on terrestrial communities}

230 Riparian predators are key organisms because they facilitate the transfer of aquatic secondary

231 production to terrestrial food webs. The diet of certain arthropod species, including carabids, 232 staphylinid beetles and spiders (Paetzold et al. 2005), as well as insectivorous birds (Iwata et 233 al. 2003), may include a large proportion of emerging an,atic insects during part of the year.

234 Some evidence suggests that the heterogeneity of strard and riparian habitats has a strong 235 influence on riverine predators. Laeser et al. (20 estimated that the abundance of spiders 236 that feed on aquatic insects along streams de re a sea by $70 \%$ after riparian vegetation was 237 removed and agricultural practices straigh, tenerl the channel. This was attributed to the loss of 238 suitable riparian habitat for web-v-aring spiders and a potential decrease in aquatic insect 239 emergence resulting from channelization. Iwata et al. (2003) also described the potential 240 detrimental effect of channelization and demonstrated that the loss of meanders in stream 241 channels decreased the abundance of aquatic insects and insectivorous birds that prey on 242 them. Carlson et al. (2016) reported that abundance of adult aquatic insects decreased more 243 rapidly away from stream banks in open agricultural streams than away from those of forest 244 streams. These results suggest that riparian vegetation can significantly modify the flux of 245 subsidies from aquatic to terrestrial ecosystems. Moreover, many riparian predators such as 246 birds (Buchanan et al. 2006) or spiders (Nentwig 1980) are size selective when preying on 247 aquatic insects. Stenroth et al. (2015) highlighted that a greater abundance of small-bodied 248 insects (e.g. Nematocera) emerging from agricultural streams was associated with greater 
abundance of riparian carabid beetles and linyphiid spiders. Therefore, the changes in aquatic

250 and riparian habitats, along with agricultural practices, can modify functional links between

251 aquatic and terrestrial food webs, and consequently the transfer efficiency of aquatic subsidies

252 to land.

\section{Stream insect subsidies and ecosystem services to agriculture}

254 Despite the growing field of research on aquatic subsidies, implications of water-to-land

255 transfers in adjacent agroecosystems and ecosystem services are rarely addressed. In

256 particular, winged adults of aquatic arthropods may sustain regulating services, most likely

257 pollination, soil fertilization and pest control. To explore the current knowledge on this issue,

258 we based our analysis on studies that quantified the cont intion of aquatic arthropods to

259 terrestrial ecological processes related to ecosystem er. ces, i.e. visiting flowers or feeding

260 on nectar/pollen for pollination, dispersal of aquarions nect biomass for fertilization and the

261 percentage of aquatic prey in the diets of nat $\mathrm{r} / \mathrm{c}$ nomaies for pest control.

\section{$262 \quad 4.1$ Pollination}

263 Seventy percent of worldwide crops lely on animal pollination, and flower-visiting insects

264 undoubtedly are the major pollinators (Klein et al. 2007). Insects also play a critical role in

265 the conservation of wild flowers (Biesmeijer 2006). The global decline in insect pollinators

266 (Potts et al. 2010), especially in agroecosystems, highlights the fundamental influence of non-

267 crop habitats (Ricketts et al. 2008), especially riparian buffer strips (Cole et al. 2015), on

268 pollination services. Although bees still receive the most public and scientific attention, the

269 importance of wild non-bee pollinators has become increasingly recognized (Garibaldi et al.

270 2013, Rader et al. 2016). However, adult aquatic insects emerging from streams have been

271 ignored as pollinators, even though they feed on nectar or pollen, or at least visit wild flowers

272 or crops (Table 1). Confirmed pollinators include many species of adult Plecoptera that 
depend on pollen as a primary energy source (Winterbourn 2005). Occasional feeding on nectar or pollen was observed for Trichoptera (Petersson and Hasselrot 1994) and aquatic Coleoptera (Hoe et al. 2017). Consumption of pollen or nectar by adults of Megaloptera had also been recorded (reviewed and observed in laboratory by Villagomez \& Contreras-Ramos, 2017). Besides hoverflies, which are active pollinators (Hass et al. 2018), many Diptera families with an aquatic larval stage, such as Chironomidae, Empididae, and Ceratopogonidae, were observed to visit flowers (Table 1). Because these Diptera families are composed of both species with aquatic or terrestrial larval stage, further studies are needed to confirm that the adults that visit flowers actually emerge from water. Additionally, adult aquatic insects that pollinate or visit flowers increase flower diversity in riparian ecosystems and thus indirectly help to sustain the community of we $-\mathrm{kn}$ cwn pollinators such as bees or hoverflies that depend on this flower diversity (C.1. 2015). In a field experiment, Stewart et al. (2017) observed an increase in the auc ity and quantity of strawberries produced near a pond compared to those in a crop halstiat. This correlates with a greater abundance of hoverflies (Syrphidae, Diptera), for which the larvae of many species are aquatic (Speight 2014). This is promising and suggestr, ine need for similar experiments near streams to assess potential effects of stream insect communities on pollination of crops and wild flowers.

Adult aquatic insects are an important part of the diet of riparian predators, such as birds and bats, some of which are active pollinators (Kunz et al. 2011, Whelan et al. 2008). For instance, species of Sylviidae (warblers) are frequently observed in riparian habitats feeding on insects and plants, and pollinating wild plants (Ford 1985; Whelan et al. 2008).

Conversely, Knight et al. (2005) observed that adult dragonflies that prey on wild bees could cause a significant decrease in plant pollination by decreasing the number of bees visiting flowers. Beyond this evidence, more studies are needed to better assess the magnitude of 
direct (flower visits) and indirect effects (beneficial or detrimental effects on other

298 pollinators) of aquatic insects on the pollination of wild plants and crops.

\subsection{Soil fertilization}

300 Rock weathering, atmospheric exchanges and the decomposition of OM provide essential

301 elements for plant growth. In agricultural landscapes, soil fertility depends largely on external inputs. However, insect outbreaks can add large amounts of nutrients to the soil via their feces or cadavers (Hunter 2001). Studies of winged aquatic insects have concluded that a small percentage (3-9\%) of their biomass ultimately returns to the stream (Jackson and Fisher 1986;

Gray 1989). Deposition traps are rarely used to measure the biomass of stream-derived insects

306 that fall to the ground per unit area (but see Stenroth et of 2015); however, some authors have 307 placed interception traps at multiple distances from sfferns (Table 2). The biomass of aquatic 308 invertebrates trapped can be regarded as biomas seposition on the ground per unit area, and 309 converted into $\mathrm{N}$ assuming that the dry mass $0^{+}$igver ebrates contains $10 \% \mathrm{~N}$ (Fagan et al. 310 2003). These calculations show that strear-de ived $\mathrm{N}$ deposition to land can vary during 311 outbreaks from 1.5-12.5 mg.m $\mathrm{m}^{-2} \cdot \mathrm{d}^{-1}$ near the stream, depending on the study (Table 2).

312 Deposition decreases as the distance fiom the stream increases, but still reaches 0.7-3.0

$313 \mathrm{mg} \cdot \mathrm{m}^{-2} \cdot \mathrm{d}^{-1} 10-50 \mathrm{~m}$ away and up to $1.5 \mathrm{mg} \cdot \mathrm{m}^{-2} \cdot \mathrm{d}^{-1} 150 \mathrm{~m}$ away. Most published studies were 314 conducted along forest streams, but the amount of aquatic subsidies is likely greater along 315 agricultural streams, especially for small dipterans (chironomids) that disperse farther. From 316200 studies of stream production, Finlay (2011) estimated that secondary production of 317 macroinvertebrates is 7 times as great in human-impacted streams as in pristine streams. In 318 Sweden, Carlson et al. (2016) found 10 times as many aquatic insects $1 \mathrm{~m}$ from, and 5 times 319 as many $50 \mathrm{~m}$ from, small streams ( $<8 \mathrm{~m}$ wide) in agricultural landscapes compared to those 320 in forests. Large rivers ( $>16 \mathrm{~m}$ wide) can export 4 times as many aquatic insects to land as 321 smaller rivers (Gratton and Zanden 2009). Consequently, the amount of aquatic-derived $\mathrm{N}$ in 
agroecosystems (Table 2) may be significantly underestimated. In comparison, this phenomenon may equal or even exceed current amounts of atmospheric $\mathrm{N}$ deposition in temperate regions (i.e. mean of $55 \mathrm{~g} \mathrm{~N} \cdot \mathrm{ha}^{-1} \cdot \mathrm{d}^{-1}$, calculated from Krupa 2003), at least occasionally and near streams. Where agriculture is intensive and streams are highly productive, further research is required to estimate nutrient inputs per year and unit area of cropland that stream insects could transfer to agricultural landscapes.

\subsection{Crop pest control}

Biocontrol is commonly considered a relevant alternative to the use of chemicals. It relies on a wide diversity of natural enemies, including insects and spiders (Landis et al. 2000). A rich and abundant natural enemy community facilitates the control of pest outbreaks (Landis et al. 2000). The direct role of adult aquatic insects in pest $c$ tirol is rarely demonstrated; however, Yasumatsu et al. (1975) observed odonates in ricererds preying on several defoliators and stem borers. Many potential biocontrol agen 1 y a a a a insects (Table 3), including spiders (Linyphiidae, Lycosidae, Salticidas, Thomisidae; Riechert and Lockley 1984) and carabids (Symondson et al. 2006) Bocause aquatic prey usually emerge in pulses in early spring for instance in temperate regions, they may be essential for sustaining natural enemy populations when crop pests are scarce and more likely to be controlled (Wissinger 1997). Riparian predators can shift from aquatic-derived prey in riparian habitats to crop pests later in spring or summer, following a process of seasonal predator spillover, as described for other adjacent ecosystems (French et al. 2001; Rand et al. 2006). For instance, bats and birds that actively feed on aquatic insects in riparian habitats were effective at reducing pest abundance and thus indirectly increasing crop yield, especially in tropical agroforestry (Maas et al. 2016). This cascading effect requires that the emergence and dispersal of aquatic insects matches the timing of riparian predator food needs when terrestrial subsidies are low. In their review, Larsen et al. (2015) highlighted that global environmental changes may threaten this 
synchronicity, especially when the phenology and distribution of stream and riparian

348 organisms are altered. This synchronicity could be threatened in agroecosystems in which the

349 magnitude and quality of aquatic subsidies change greatly (see sections $2 \& 3$ ). Finally,

350 alternative prey from aquatic ecosystems may distract natural enemies from pests and thus

351 decrease the effectiveness of biocontrol (Symondson et al. 2006; Birkhofer et al. 2008). The

352 considerable amount of aquatic biomass exported from large rivers (Gratton and Zanden

353 2009) probably has a significant effect on terrestrial food webs, including disruptions in

354 biological control services. The multifaceted trophic interactions between stream invertebrate

355 prey and terrestrial predators in agroecosystems require further studies to assess the influence

356 on crop pest control.

\section{Conclusion}

358 Freshwater ecosystems have been traditionally vien ec as passive receivers of terrestrial

359 subsidies that result from agricultural practic $f$ wetersheds. However, consideration of the

360 reciprocal subsidies supported by the emergerse of adult aquatic insects could cause this

361 simplistic assessment to be reeval intedensification of agriculture resulted in massive use

362 of chemical inputs and great changes to the landscape, which has decreased biodiversity and

363 ecosystem functioning worldwide. In this context, it is critical to encourage a new model

364 developed for sustainable agricultural practices that relies on the ecological processes that

365 ecosystems provide. In this review, we highlighted promising scientific evidence that winged

366 aquatic insects can support pollination, soil fertilization and the control of crop pests in

367 agroecosystems. The influence of land-use and agricultural practices on the amount and type

368 of emerging aquatic insects requires more thorough investigation. Studies of aquatic subsidies

369 associated with the dispersal of stream insect communities in agricultural landscapes are

370 essential for a comprehensive approach to the variety of ecosystem services provided in

371 agroecosystems. Future research on aquatic subsidies in agricultural landscapes could 
372 strengthen understanding of ecosystem services and their management, while simultaneously

373 meeting conservation goals for freshwater biodiversity to ensure optimal ecosystem

374 functioning.

375 Acknowledgements

376 This study received financial support from the EcoServ program of the French National

377 Institute for Agronomic Research (INRA) (for J.-M. Roussel) and from the French Ministry

378 for Research (Ph.D. grant, 2015-2018) (for J. Raitif). 
Table 1. Observed pollination or flower visits of aquatic insect taxa

\begin{tabular}{|c|c|c|}
\hline Reference & Country & Aquatic insects involved ${ }^{\mathrm{a}}$ \\
\hline Chartier et al., 2011 & France, Spain & Diptera (Chironomidae, Psychodidae, Ceratopogonidae) \\
\hline $\begin{array}{l}\text { de Figueroa \& Sánchez- } \\
\text { Ortega, } 2000\end{array}$ & Spain & Plecoptera \\
\hline Gilbert, 1981 & England & Syrphidae (Diptera) \\
\hline Hass et al., 2018 & $\begin{array}{l}\text { France, Germany, Spain, } \\
\text { UK }\end{array}$ & Syrmoidae (Diptera) \\
\hline Hoe et al., 2017 & Indonesia \& Malaysia & Hydropili dac (Coleoptera) \\
\hline Kato et al., 1990 & Japan & $\begin{array}{l}\text { Diptera (Syrphisae, Erpidae, Anthomyiidae, Tipulidae, Chironmidae), Hemiptera, Coleoptera } \\
\text { (Curculionidae), }\end{array}$ \\
\hline Kevan, 1972 & Canada & Diptera (Chironomidae, Culic dar, Dolichopodidae, Syrphidae) \\
\hline Murza et al., 2006 & Canada & Diptera (Chironomidae, Ceratopogonidae, Dolichopodidae) \\
\hline $\begin{array}{l}\text { Petersson \& Hasselrot, } \\
1994\end{array}$ & Sweden & Trichoptera \\
\hline Robson, 2008 & Canada & Syrphidae, Stratiomydae (Diptera) \\
\hline Sato \& Kato, 2017 & Japan & Plecoptera \\
\hline
\end{tabular}


Thien et al., 1983

USA

Laboratory

Ramos 2017

Winterbourn, 2005

New-Zealand
Diptera (Chironomidae, Culicidae), Plecoptera, Trichoptera

\section{Megaloptera}

\section{Plecoptera}

a: Dipterans cited as flower visitors in these studies were rarely identified to the species level. Since these studies were performed near streams or other water bodies, however, we assumed that the dipterans were mostly aquatic species.

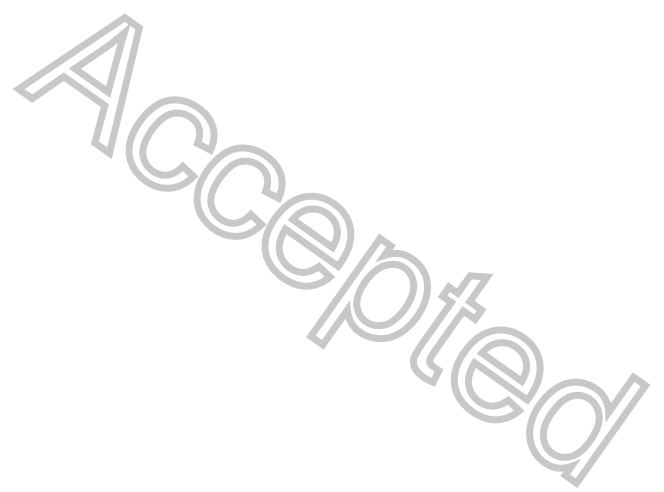


Table 2. Published estimates of the dry mass of dispersing winged aquatic insects trapped at multiple distances from streams and their equivalent nitrogen $(\mathrm{N})$ deposits during outbreaks

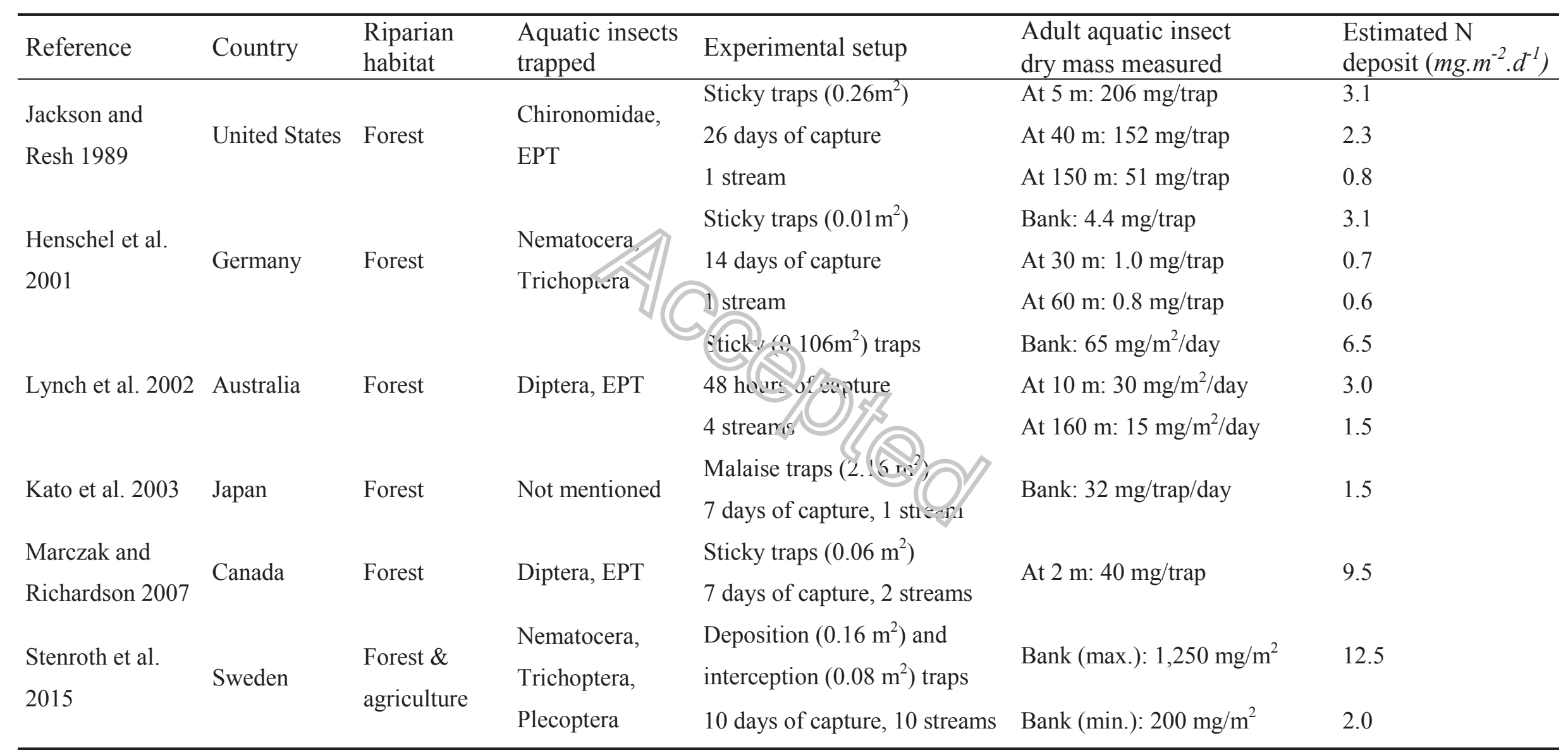

See text for details of calculating N deposition, which should not be extrapolated beyond outbreak periods. EPT stands for Ephemeroptera, Plecoptera and Trichoptera. 
Table 3. Percentage of aquatic prey in the diets of terrestrial arthropod predators that are potential natural enemies of crop pests

\begin{tabular}{|c|c|c|c|c|}
\hline Reference & Country & Riparian habitats & Terrestrial natural enemies & $\begin{array}{l}\text { Percentage aquatic } \\
\text { prey }(\%)\end{array}$ \\
\hline $\begin{array}{l}\text { Akamatsu et al. } \\
2004\end{array}$ & Japan & Forests and grasses & Spiders & $54-92$ \\
\hline Davis et al. 2011 & United States & Forests & Spiders (Tetragnathidae, Araneidae, Linyphiidae) & $12-100$ \\
\hline Gergs et al. 2014 & Germany & Forests & Spiders (Tetragnathidae, Lycodisae) & $13-77$ \\
\hline Henschel et al. 2001 & Germany & Forests & $\begin{array}{l}\text { Spiders (Tetragnathidae, Lycodisae, Linyphiidae) } \\
\text { (10) pleoptera) }\end{array}$ & $\begin{array}{r}24-53 \\
11-20 \\
0-29\end{array}$ \\
\hline $\begin{array}{l}\text { Hering and Plachter, } \\
1997\end{array}$ & Germany & Unspecified & Coleopturd(Carabidae) & 89 \\
\hline Paetzold et al. 2005 & $\begin{array}{l}\text { Switzerland and } \\
\text { Italy }\end{array}$ & Forests & $\begin{array}{l}\text { Coleoptera (Staphytil (ae) } \\
\text { Spiders (Lycosidae) }\end{array}$ & $\begin{array}{l}80 \\
56\end{array}$ \\
\hline Sanzone et al. 2003 & United States & Forests & $\begin{array}{l}\text { Spiders (Araneidae, Tetragnathidae, Salticidae, } \\
\text { Thomisidae, Lycosidae) }\end{array}$ & $68-100$ \\
\hline Stenroth et al. 2015 & Sweden & & Sipders (Lycosidae, Linyphiidae) & $44-60$ \\
\hline & & & Carabidae & 43 \\
\hline
\end{tabular}


Akamatsu F, Toda H, Okino T (2004) Food source of riparian spiders analyzed by using stable isotope ratios. Ecol Res 19:655-662 . doi: 10.1111/j.1440-1703.2004.00680.x

Allan, J. D. (2004). Landscapes and Riverscapes: The Influence of Land Use on Stream Ecosystems. Annual Review of Ecology, Evolution, and Systematics, 35(1), 257-284. https://doi.org/10.1146/annurev.ecolsys.35.120202.110122

Ballinger A, Lake PS (2006) Energy and nutrient fluxes from rivers and streams into terrestrial food webs. Marine and Freshwater Research 57:15 . doi: 10.1071/MF05154

Baxter CV, Fausch KD, Carl Saunders W (2005) Tangled webs: reciprocal flows of invertebrate prey link streams and riparian zones: Prey subsidies link stream and riparian food webs. Freshw Biol 50:201-220 . doi: 10.1111/j.1365-2427.2004.01328.x

Beketov MA, Kefford BJ, Schafer RB, Liess M (2013) Pesticides reduce regional biodiversity of stream invertebrates. Proc Natl Acad Sci 110:11039-11043 . doi: $10.1073 /$ pnas. 1305618110

Bellamy AR, Bauer JE, Grottoli AG (2017) Influence o lan use and lithology on sources and ages of nutritional resources for stream marominertebrates: a multi-isotopic approach. Aquat Sci 79:925-939 . doi: 10 1.00.7s 0027-017-0542-3

Biesmeijer JC (2006) Parallel Declines in Pollititors and Insect-Pollinated Plants in Britain and the Netherlands. Science 313:351 4. doi: 10.1126/science.1127863

Birkhofer K, Wise DH, Scheu S (2008) S bsicy from the detrital food web, but not microhabitat complexity, affect the role of generalist predators in an aboveground herbivore food web. Oikos 117.494-500 . doi: 10.1111/j.0030-1299.2008.16361.x

Brett MT, Bunn SE, Chandra S, Gal (wway A.W.E., Guo F, Kainz M J, ..., Wehr J.D. (2017) How important are terrestrial organic carbon inputs for secondary production in freshwater ecosystems? Freshw Biol 62:833-853 . doi: 10.1111/fwb.12909

Brittain JE, Saltveit SJ (1989) A review of the effect of river regulation on mayflies (Ephemeroptera). Regul Rivers Res Manag 3:191-204 . doi: 10.1002/rrr.3450030119

Brown AV, Brussock PP (1991) Comparisons of benthic invertebrates between riffles and pools. Hydrobiologia 220:99-108 . doi: 10.1007/BF00006542

Buchanan, G. M., Grant, M. C., Sanderson, R. A., \& Pearce-Higgins, J. W. (2006). The contribution of invertebrate taxa to moorland bird diets and the potential implications of land-use management: Moorland bird diets. Ibis, 148(4), 615-628. https://doi.org/10.1111/j.1474-919X.2006.00578.x

Bunn SE, Arthington AH (2002) Basic Principles and Ecological Consequences of Altered Flow Regimes for Aquatic Biodiversity. Environ Manage 30:492-507 . doi: $10.1007 / \mathrm{s} 00267-002-2737-0$ 
Burdon FJ, McIntosh AR, Harding JS (2013) Habitat loss drives threshold response of benthic invertebrate communities to deposited sediment in agricultural streams. Ecol Appl Publ Ecol Soc Am 23:1036-1047. doi: 10.1890/12-1190.1

Carlson PE, McKie BG, Sandin L, Johnson RK (2016) Strong land-use effects on the dispersal patterns of adult stream insects: implications for transfers of aquatic subsidies to terrestrial consumers. Freshw Biol 61:848-861 . doi: 10.1111/fwb.12745

Chartier M, Pélozuelo L, Gibernau M (2011) Do floral odor profiles geographically vary with the degree of specificity for pollinators? Investigation in two sapromyophilous Arum species (Araceae). Ann Société Entomol Fr NS 47:71-77. doi: 10.1080/00379271.2011.10697698

Cole, L. J., Brocklehurst, S., Robertson, D., Harrison, W., \& McCracken, D. I. (2015). Riparian buffer strips: Their role in the conservation of insect pollinators in intensive grassland systems. Agriculture, Ecosystems \& Environment, 211, 207-220. https://doi.org/10.1016/j.agee.2015.06.012

Cross WF, Wallace JB, Rosemond AD, Eggert SL (2006) Whole-system nutrient enrichment increases secondary production in a detritus-based ecosystem. Ecology 87:1556-1565 . doi: 10.1890/0012-9658(2006)87[1556:WNEIS: $]$ ?.CO;2

Davis JM, Rosemond AD, Small GE (2011) Increasilig ác nor ecosystem productivity decreases terrestrial consumer reliance on $x+r c a n$ resource subsidy. Oecologia 167:821-834 . doi: 10.1007/s00442-011 20. 5-9

de Figueroa JMT, Sánchez-Ortega A (2000) Fratgina Feeding of Twelve Nemouroidean Stonefly Species (Insecta, Plecoptera). Ain Entomol Soc Am 93:251-253. doi: 10.1603/0013-8746(2000)093[025:IFOTNS]2.0.CO;2

Deegan BM, Ganf GG (2008) The loss of aquatic and riparian plant communities: Implications for their consum is in a riverine food web. Austral Ecol 33:672-683 . doi: $10.1111 / \mathrm{j} .1442-9993.200 \$ .01834 . x$

Delettre YR, Morvan N (2000) Dispersal of adult aquatic Chironomidae (Diptera) in agricultural landscapes. Freshw Biol 44:399-411 . doi: 10.1046/j.13652427.2000.00578.x

Dole-Olivier M-J (2011) The hyporheic refuge hypothesis reconsidered: a review of hydrological aspects. Mar Freshw Res 62:1281 . doi: 10.1071/MF11084

Dreyer J, Hoekman D, Gratton C (2012) Lake-derived midges increase abundance of shoreline terrestrial arthropods via multiple trophic pathways. Oikos 121:252-258 . doi: 10.1111/j.1600-0706.2011.19588.x

Fagan WF, Siemann E, Mitter C, Denno R.F., Huberty A.F., Woods H.A., Else J.J. (2003) Nitrogen in Insects: Implications for Trophic Complexity and Species Diversification. Am Nat 160:784-802 . doi: 10.1086/343879

Finlay JC (2011) Stream size and human influences on ecosystem production in river networks. Ecosphere 2:1-21 . doi: 10.1890/ES11-00071.1 
Ford HA (1985) Nectarivory and Pollination by Birds in Southern Australia and Europe. Oikos 44:127 . doi: 10.2307/3544053

French BW, Elliott NC, Berberet RC, Burd JD (2001) Effects of Riparian and Grassland Habitats on Ground Beetle (Coleoptera: Carabidae) Assemblages in Adjacent Wheat Fields. Environ Entomol 30:225-234 . doi: 10.1603/0046-225X-30.2.225

Galloway JN, Townsend AR, Erisman JW, Bekunda M, Cai Z, Freney JR, ..., Sutton MA (2008) Transformation of the Nitrogen Cycle: Recent Trends, Questions, and Potential Solutions. Science 320:889-892 . doi: 10.1126/science.1136674

Garibaldi, L. A., Steffan-Dewenter, I., Winfree, R., Aizen, M. A., Bommarco, R., Cunningham, S. A., ... Klein, A. M. (2013). Wild Pollinators Enhance Fruit Set of Crops Regardless of Honey Bee Abundance. Science, 339(6127), 1608-1611. https://doi.org/10.1126/science. 1230200

Gergs R, Koester M, Schulz RS, Schulz R (2014) Potential alteration of cross-ecosystem resource subsidies by an invasive aquatic macroinvertebrate: implications for the terrestrial food web. Freshw Biol 59:2645-2655 . doi: 10.1111/fwb.12463

Gilbert FS (1981) Foraging ecology of hoverflies: morp feeding on nectar and pollen in some common urar species. Ecol Entomol 6:245-262 . doi: 10.1111/j.1365-2311.1981.tb00612.x

Gratton C, Zanden MJV (2009) Flux of aquatic iseter productivity to land: comparison of lentic and lotic ecosystems. Ecology 90:2689)-2699 . doi: 10.1890/08-1546.1

Gray LJ (1989) Emergence Production and cxint of Aquatic Insects from a Tallgrass Prairie Stream. Southwest Nat 34:313 . do - 10).2307/3672158

Greenwood MJ, Booker DJ (2016) Influence of hydrological regime and land cover on traits and potential export capacity ad ault aquatic insects from river channels. Oecologia 180:551-566 . doi: $10.1007 / \mathrm{s}, 0442-015-3462-8$

Haidekker A, Hering D (2008) Relationship between benthic insects (Ephemeroptera, Plecoptera, Coleoptera, Trichoptera) and temperature in small and medium-sized streams in Germany: A multivariate study. Aquat Ecol 42:463-481 . doi: 10.1007/s10452-007-9097-z

Hass AL, Kormann UG, Tscharntke T, et al (2018) Landscape configurational heterogeneity by small-scale agriculture, not crop diversity, maintains pollinators and plant reproduction in western Europe. Proc R Soc B 285:20172242. doi: $10.1098 /$ rspb.2017.2242

Havik G, Catenazzi A, Holmgren M (2014) Seabird Nutrient Subsidies Benefit Non-Nitrogen Fixing Trees and Alter Species Composition in South American Coastal Dry Forests. PLoS ONE 9:e86381 . doi: 10.1371/journal.pone.0086381

Henschel JR, Mahsberg D, Stumpf H (2001) Allochthonous aquatic insects increase predation and decrease herbivory in river shore food webs. Oikos 93:429-438 . doi: 10.1034/j.1600-0706.2001.930308.x 
Hering D, Plachter H (1997) Riparian ground beetles (Coeloptera, Carabidae) preying on aquatic invertebrates: a feeding strategy in alpine floodplains. Oecologia 111:261-270 . doi: $10.1007 / \mathrm{s} 004420050234$

Hoe YC, Gibernau M, Wong SY (2017) Diversity of pollination ecology in the Schismatoglottis Calyptrata Complex Clade (Araceae). Plant Biol 20:563-578. doi: 10.1111/plb.12687

Holt RD (1997) From Metapopulation Dynamics to Community Structure. In: Metapopulation Biology. Elsevier, pp 149-164

Hunter MD (2001) Insect population dynamics meets ecosystem ecology: effects of herbivory on soil nutrient dynamics. Agric For Entomol 3:77-84 . doi: 10.1046/j.14619563.2001.00100.x

Hyndes GA, Nagelkerken I, McLeod RJ, Connoly RM, Lavery PS, Vanderklift MA (2014) Mechanisms and ecological role of carbon transfer within coastal seascapes: Carbon transfer within coastal seascapes. Biol Rev 89:232-254 . doi: 10.1111/brv.12055

Iwata T, Nakano S, Murakami M (2003) Stream Meanders Increase Insectivorous Bird Abundance in Riparian Deciduous Forests. Ecog, upte 26:325-337. doi: 10.1034/j.1600-0587.2003.03355.x

Jackson JK, Fisher SG (1986) Secondary Production, Emergence, and Export of Aquatic Insects of a Sonoran Desert Stream. Ecolog. 07:629 . doi: 10.2307/1937686

Jackson JK, Resh VH (1989) Distribution an the the ance of Adult Aquatic Insects in the Forest Adjacent to a Northern Californs stream. Environ Entomol 18:278-283 . doi: 10.1093/ee/18.2.278

Kato C, Iwata T, Nakano S, Kishi D (2003, Dynamics of aquatic insect flux affects distribution of riparian web by laing spiders. Oikos 103:113-120 . doi: 10.1034/j.1600-0706.2003.12 $777 . \mathrm{x}$

Kato M, Kakutani T., Inoue T., Itino T. (1990) Insect-flower relationship in the primary beech forest of Ashu, Kyoto: an overview of the flowering phenology and the seasonal pattern from insect visits. Contrib Biol Lab Kyoto Univ 309-375

Kennedy TL, Turner TF (2011) River channelization reduces nutrient flow and macroinvertebrate diversity at the aquatic terrestrial transition zone. Ecosphere 2:art35 . doi: 10.1890/ES11-00047.1

Kevan PG (1972) Insect Pollination of High Arctic Flowers. J Ecol 60:831 . doi: $10.2307 / 2258569$

Kiffney, P. M., Richardson, J. S., \& Bull, J. P. (2003). Responses of periphyton and insects to experimental manipulation of riparian buffer width along forest streams. Journal of Applied Ecology, 40(6), 1060-1076. https://doi.org/10.1111/j.13652664.2003.00855.x 
Klein A-M, Vaissiere BE, Cane JH, Steffan-Dewenter I, Cunningham SA, Kremen C, Tscharntke T (2007) Importance of pollinators in changing landscapes for world crops. Proc R Soc B Biol Sci 274:303-313 . doi: 10.1098/rspb.2006.3721

Knight TM, McCoy MW, Chase JM, McCoy KA, Holt RD (2005) Trophic cascades across ecosystems. Nature 437:880-883 . doi: 10.1038/nature03962

Kostecki C, Le Loc'h F, Roussel J-M, Desroy N, Huteau D, Riera P,...,Le Pape O (2010) Dynamics of an estuarine nursery ground: the spatio-temporal relationship between the river flow and the food web of the juvenile common sole (Solea solea, L.) as revealed by stable isotopes analysis. J Sea Res 64:54-60 . doi: 10.1016/j.seares.2009.07.006

Krupa S. (2003) Effects of atmospheric ammonia (NH3) on terrestrial vegetation: a review. Environ Pollut 124:179-221 . doi: 10.1016/S0269-7491(02)00434-7

Kunz TH, Torrez EB de, Bauer D, et al (2011) Ecosystem services provided by bats. Ann N Y Acad Sci 1223:1-38. doi: 10.1111/j.1749-6632.2011.06004.X

Laeser, S. R., Baxter, C. V., \& Fausch, K. D. (2005). Rinarian vegetation loss, stream channelization, and web-weaving spiders in nort'.... Japan. Ecological Research, 20(6), 646-651. https://doi.org/10.1007/s11284-005/j084-3

Lancaster J (2013) Aquatic entomology, 1st ed. Oxora - niversity Press, Oxford

Landis DA, Wratten SD, Gurr GM (2000) Habit Nanagement to Conserve Natural Enemies of Arthropod Pests in Agriculture. Atno entomol 45:175-201 . doi: 10.1146/annurev.ento.45.1.175

Larsen S, Muehlbauer JD, Marti E (2010) Iesource subsidies between stream and terrestrial ecosystems under global change. Crobal Change Biology 22:2489-2504. doi: $10.1111 / \mathrm{gcb} .13182$

Lemly AD (1982) Modification of benthic insect communities in polluted streams: combined effects of sedimentation and nutrient enrichment. Hydrobiologia 87:229-245 . doi: 10.1007/BF00007232

Liess M, Von Der Ohe PC (2005) Analysing effects of pesticides on invertebrate communities in streams. Environ Toxicol Chem 24:954 . doi: 10.1897/03-652.1

Logan P, Brooker M (1983) The macroinvertebrate faunas of riffles and pools. Water Res 17:263-270 . doi: 10.1016/0043-1354(83)90179-3

Loreau M, Mouquet N, Holt RD (2003) Meta-ecosystems: a theoretical framework for a spatial ecosystem ecology. Ecology Letters 6:673-679. doi: 10.1046/j.14610248.2003.00483.x

Lu YH, Canuel EA, Bauer JE, Chambers RM (2014) Effects of watershed land use on sources and nutritional value of particulate organic matter in temperate headwater streams. Aquat Sci 76:419-436 . doi: 10.1007/s00027-014-0344-9 
Lynch RJ, Bunn SE, Catterall CP (2002) Adult aquatic insects: Potential contributors to riparian food webs in Australia's wet-dry tropics. Austral Ecol 27:515-526 . doi: 10.1046/j.1442-9993.2002.01208.x

Maas B, Karp DS, Bumrungsri S, et al (2016) Bird and bat predation services in tropical forests and agroforestry landscapes: Ecosystem services provided by tropical birds and bats. Biological Reviews 91:1081-1101. doi: 10.1111/brv.12211

Marczak LB, Richardson JS (2007) Spiders and subsidies: results from the riparian zone of a coastal temperate rainforest. J Anim Ecol 76:687-694 . doi: 10.1111/j.13652656.2007.01240.x

Marczak LB, Thompson RM, Richardson JS (2007) Meta-analysis: trophic level, habitat, and productivity shape the food web effects of resource subsidies. Ecology 88:140-148. doi: 10.1890/0012-9658(2007)88[140:MTLHAP]2.0.CO;2

Mazoyer M, Roudart L (2006) A History of World Agriculture: From the Neolithic Age to the Current Crisis. NYU Press

Muehlbauer JD, Collins SF, Doyle MW, Tockner K (2014) How wide is a stream? Spatial extent of the potential "stream signature" in terre prial food webs using meta-analysis. Ecology 95:44-55 . doi: 10.1890/12-1628.1

Munn MD, Brusven MA (1991) Benthic macroin rtobrate communities in nonregulated and regulated waters of the clearwater river, IGato, U.S.A. Regul Rivers Res Manag 6:111. doi: 10.1002/rrr.3450060102

Murza GL, Heaver JR, Davis AR (2006) M.inerellinator-prey conflict in the carnivorous plant, Drosera anglica. Plant Ecol 184:43. doi: 10.1007/s11258-005-9050-y

Nagasaka A, Nakamura F (1999) The intences of land-use changes on hydrology and riparian environment in a nortsent Japanese landscape. Landsc Ecol 14:543-556 . doi: 10.1023/A:1008164123102

Nakano S, Murakami M (2001) Reciprocal subsidies: Dynamic interdependence between terrestrial and aquatic food webs. Proc Natl Acad Sci U S A 98:166-170. doi: 10.1073/pnas.98.1.166

Negishi JN, Inoue M, Nunokawa M (2002) Effects of channelisation on stream habitat in relation to a spate and flow refugia for macroinvertebrates in northern Japan. Freshw Biol 47:1515-1529 . doi: 10.1046/j.1365-2427.2002.00877.x

Nentwig, W. (1980). The selective prey of linyphiid-like spiders and of their space webs. Oecologia, 45(2), 236-243. https://doi.org/10.1007/BF00346464

Odum EP, Finn JT, Franz EH (1979) Perturbation Theory and the Subsidy-Stress Gradient. BioScience 29:349-352. doi: 10.2307/1307690

Paetzold A, Schubert CJ, Tockner K (2005) Aquatic Terrestrial Linkages Along a BraidedRiver: Riparian Arthropods Feeding on Aquatic Insects. Ecosystems 8:748-759 . doi: 10.1007/s10021-005-0004-y 
Petersson E, Hasselrot A t. (1994) Mating and nectar feeding in the psychomyiid caddis fly Tinodes waeneri. Aquat Insects 16:177-187. doi: 10.1080/01650429409361553

Poff NL, Pyne MI, Bledsoe BP, Cuhaciyan C, Carlisle DM (2010) Developing linkages between species traits and multiscaled environmental variation to explore vulnerability of stream benthic communities to climate change. J North Am Benthol Soc 29:14411458 . doi: $10.1899 / 10-030.1$

Polis GA, Anderson WB, Holt RD (1997) Toward an integration of landscape and food web ecology: the dynamics of spatially subsidized food webs. Annu Rev Ecol Syst 289316. doi: https://doi.org/10.1146/annurev.ecolsys.28.1.289

Polis GA, Hurd SD (1995) Extraordinarily high spider densities on islands: flow of energy from the marine to terrestrial food webs and the absence of predation. Proc Natl Acad Sci 92:4382-4386

Potts SG, Biesmeijer JC, Kremen C, et al (2010) Global pollinator declines: trends, impacts and drivers. Trends Ecol Evol 25:345-353. doi: 10.1016/j.tree.2010.01.007

Rabení CF, Doisy KE, Zweig LD (2005) Stream invertebrate community functional responses to deposited sediment. Aquat Sci 67:395-402 . dei. 10.1007/s00027-005-0793-2

Rader R, Bartomeus I, Garibaldi LA, Garratt MPD, Fox Ieı BG, Winfree R,..., Andersson GKS (2016) Non-bee insects are importari critritors to global crop pollination. Proc Natl Acad Sci 113:146-151 . doi: 10 1, S pnas.1517092112

Raitif, J., Plantegenest, M., Agator, O., Piscar, fr, Roussel, J.-M. (2018). Seasonal and spatial variations of stream insect em serice in an intensive agricultural landscape. Science of The Total Environmen:64 4 , 594-601. https://doi.org/10.1016/j.scitoter. 2 .2 18.07 .021

Rand TA, Tylianakis JM, Tscharnike T006) Spillover edge effects: the dispersal of agriculturally subsidized inscct natural enemies into adjacent natural habitats. Ecol Lett 9:603-614 . doi: 10.1111/j.1461-0248.2006.00911.x

Ricketts, T. H., Regetz, J., Steffan-Dewenter, I., Cunningham, S. A., Kremen, C., Bogdanski, A., ... Viana, B. F. (2008). Landscape effects on crop pollination services: are there general patterns? Ecology Letters, 11(5), 499-515. https://doi.org/10.1111/j.14610248.2008.01157.x

Riechert SE, Lockley T (1984) Spiders as Biological Control Agents. Annu Rev Entomol 29:299-320 . doi: 10.1146/annurev.en.29.010184.001503

Robson DB (2008) The structure of the flower-insect visitor system in tall-grass prairie. Botany 86:1266-1278 . doi: 10.1139/B08-083

Roussel J-M, Perrier C, Erkinaro J, Niemelä E, Cunjak RA, Huteau D, Riera P (2014) Stable isotope analyses on archived fish scales reveal the long-term effect of nitrogen loads on carbon cycling in rivers. Glob Change Biol 20:523-530 . doi: 10.1111/gcb.12293 
Sabo JL, Power ME (2002) River-watershed exchange : effects of riverine subsidies on riparian lizards and their terrestrial prey. Ecology 83:1860-1869 . doi: 10.1890/00129658(2002)083[1860:RWEEOR]2.0.CO;2

Sanzone DM, Meyer JL, Marti E, Gardiner EP, Tank JL, Grimm NB (2003) Carbon and nitrogen transfer from a desert stream to riparian predators. Oecologia 134:238-250 . doi: $10.1007 / \mathrm{s} 00442-002-1113-3$

Sato AAW, Kato M (2017) Pollination system of Corylopsis gotoana (Hamamelidaceae) and its stonefly (Plecoptera) co-pollinator. Plant Species Biol 32:440-447. doi: 10.1111/1442-1984.12178

Schulz R, Bundschuh M, Gergs R, Brühl CA, Diehl D, Entling MH, Fahse L, Frör O, Jungkunst HF, Lorke A, Schäfer RB, Schaumann GE, Schwenk K (2015) Review on environmental alterations propagating from aquatic to terrestrial ecosystems. Science of the Total Environment 538: 246-261

Speight (2014). Species accounts of European Syrphidae (Diptera). Syrph the Net, the Database of European Syrphidae, 78, 321.

Sponseller RA, Benfield EF, Valett HM (2001) Relation thios between land use, spatial scale and stream macroinvertebrate communities. Fres fxu Biol 46:1409-1424 . doi: 10.1046/j.1365-2427.2001.00758.x

Summerhayes VS, Elton CS (1923) Contributiorste the ecology of Spitsbergen and Bear Island. J Ecol 11:216 . doi: 10.2307/225586.

Symondson WOC, Cesarini S, Dodd PW, Harne GL, Bruford MW, Glen DM,..., Harwood JD (2006) Biodiversity vs. bioconirol: yositive and negative effects of alternative prey on control of slugs by carabid teetles. Bull Entomol Res 96:637-645 . doi: 10.1079/BER2006467

Thien LB, White DA, Yatsu LY (1983) The Reproductive Biology of a Relict-Illicium floridanum Ellis. Am J Bot 70:719 . doi: 10.2307/2443126

Vannote RL, Minshall GW, Cummins KW, Sedell JR, Cushing CE (1980) The River Continuum Concept. Can J Fish Aquat Sci 37:130-137 . doi: 10.1139/f80-017

Vannote RL, Sweeney BW (1980) Geographic Analysis of Thermal Equilibria: A Conceptual Model for Evaluating the Effect of Natural and Modified Thermal Regimes on Aquatic Insect Communities. Am Nat 115:667-695 . doi: 10.1086/283591

Villagomez F, Contreras-Ramos A (2017) First records of adult feeding in Megaloptera (Corydalidae, Corydalinae) from Mexico and their possible relationship with the increase in life span. Zootaxa 4341:287. doi: 10.11646/zootaxa.4341.2.11

Wagenhoff A, Townsend CR, Phillips N, Matthaei CD (2011) Subsidy-stress and multiplestressor effects along gradients of deposited fine sediment and dissolved nutrients in a regional set of streams and rivers: Sediment and nutrients in streams. Freshw Biol 56:1916-1936 . doi: 10.1111/j.1365-2427.2011.02619.x 
Ward JV, Stanford JA (1982) Thermal Responses in the Evolutionary Ecology of Aquatic Insects. Annu Rev Entomol 27:97-117 . doi: 10.1146/annurev.en.27.010182.000525

Webb BW, Hannah DM, Moore RD, Brown RD, Nobilis F (2008) Recent advances in stream and river temperature research. Hydrol Process 22:902-918 . doi: 10.1002/hyp.6994

Whelan CJ, Wenny DG, Marquis RJ (2008) Ecosystem Services Provided by Birds. Ann N Y Acad Sci 1134:25-60 . doi: 10.1196/annals.1439.003

Winterbourn MJ (2005) Dispersal, feeding and parasitism of adult stoneflies (Plecoptera) at a New Zealand forest stream. Aquat Insects 27:155-166. doi: $10.1080 / 01650420500062840$

Wissinger SA (1997) Cyclic Colonization in Predictably Ephemeral Habitats: A Template for Biological Control in Annual Crop Systems. Biol Control 10:4-15 . doi: 10.1006/bcon.1997.0543

Wogram J, Liess M (2001) Rank Ordering of Macroinvertebrate Species Sensitivityto Toxic Compounds by Comparison with That of Daphnia magna. Bull Environ Contam Toxicol 67:360-367 . doi: 10.1007/s001280133

Yasumatsu, Wongsiri, Navavichit, Tirawat (1975) Apprach, es toward an integrated control of rice pests. Pt. 1: Survey of natural enemies of (15.) fortant rice pests in Thailand. Plant protection service technical bulletin 24 . 

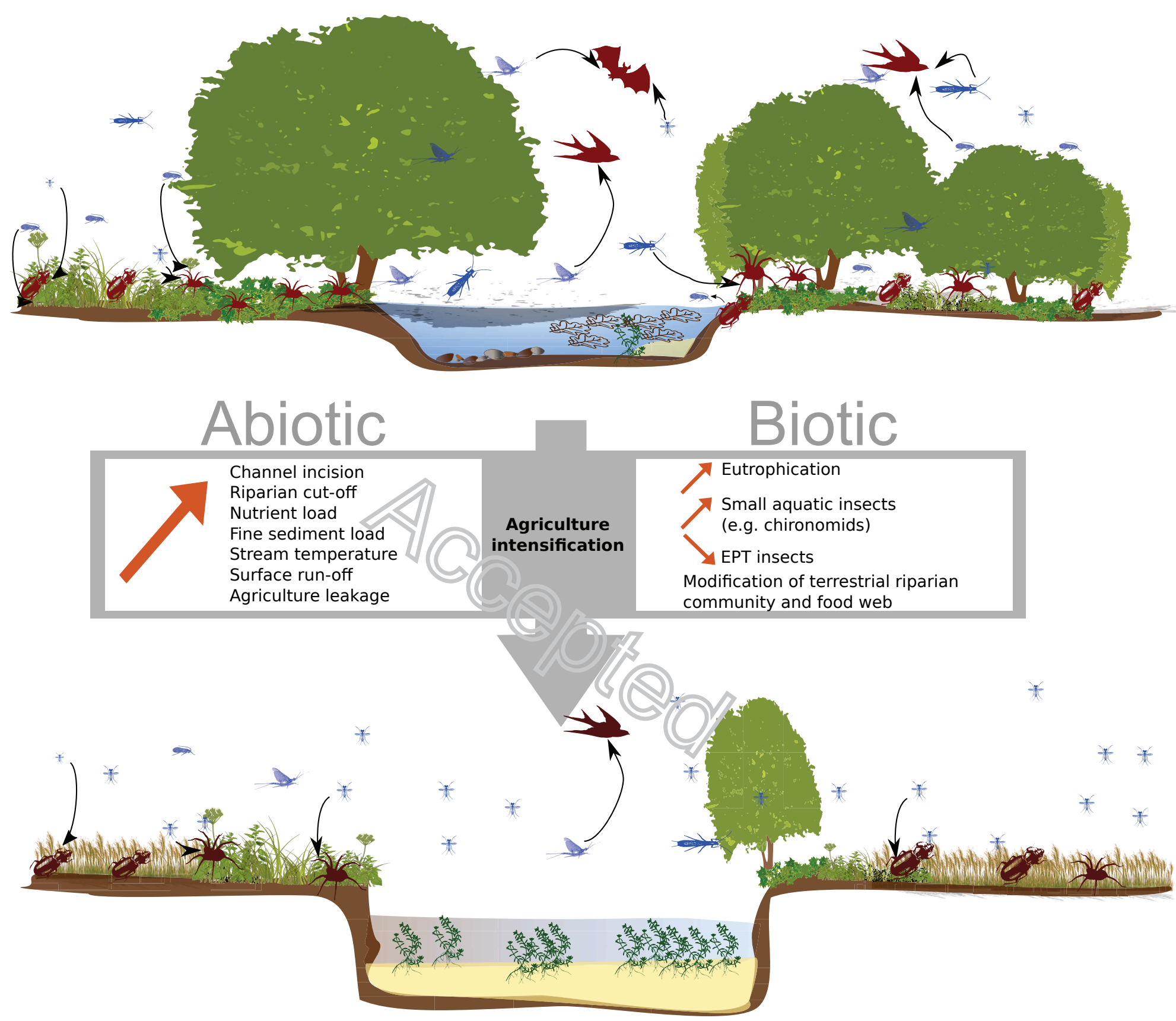
Fig. 1. Effect of agriculture intensification on stream insect community and aquatic subsidies. Aquatic insects (blue), terrestrial predators (red) and trophic links (black arrows) are indicated. Top: a stream with heterogeneous aquatic habitat (substrate, light, water temperature, food source, and hydraulic conditions), dense riparian vegetation and a rich community of winged adult aquatic insects. Trophic links between ecosystems involve many aquatic and terrestrial taxa. Bottom: agriculture intensification induces strong effect on abiotic parameters in the stream, leading to changes of aquatic communities. Community of winged stream insects is less diverse, notably with fewer sensitive taxa (Ephemeroptera and Plecoptera) and the dominance of smaller Chironomidae. Community of terrestrial predators (e.g. birds, bats, spiders) is also impacted.

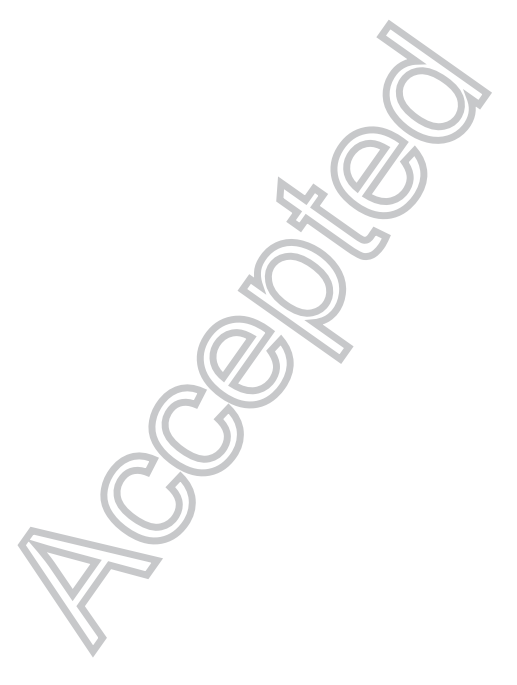

